\title{
Driving and Restraining Factors of Posdaya as Family Empowerment Program
}

\author{
Pudji Muljono ${ }^{1}$ \\ ${ }^{1}$ Faculty of Human Ecology, Bogor Agricultural University, Indonesia \\ Correspondence: Pudji Muljono, Kampus IPB Darmaga, Bogor, Indonesia. E-mail: pudji1962@yahoo.co.id; \\ pudjimuljono@gmail.com
}

$\begin{array}{lc}\text { Received: August 20, } 2014 & \text { Accepted: September 1, } 2014 \quad \text { Online Published: November 4, } 2014 \\ \text { doi:10.5539/jsd.v7n6p84 } & \text { URL: http://dx.doi.org/10.5539/jsd.v7n6p84 }\end{array}$

\begin{abstract}
In order to oversee the process of growth, development and coaching Posdaya contained in the various regions, necessary to study the factors supporting and restraining the development of Posdaya. This study is needed to determine the factors supporting and restraining Posdaya for each field of activity, which in turn can be followed up with proper guidance and effective in every area of activity. The respondents of this study consisting of 250 people from the board and stakeholders of Posdaya in Bogor City and Bogor District. Data collection procedures and data analysis performed using force field analysis. The analysis showed that the most prominent driving factor for the economic, education, health and the environment: there is business activities based on local resources; there is always a tough and skilled cadre; regular program service centre, Posbindu, Posyandu; and the spirit of mutual cooperation and self reliance. Meanwhile, the most prominent obstacle to the economic, education, health and the environment: there is not been known to the market, soft skills of Posdaya cadre are still low, healthy culture is low, and the presumption Posdaya as project. Based on the results of the analysis can be developed appropriate programs and activities to improve performance and overcome the weaknesses of Posdaya.
\end{abstract}

Keywords: community empowerment, driving factor, family empowerment, Posdaya, restraining factor

\section{Introduction}

According to Suyono and Haryanto (2009) Pos Pemberdayaan Keluarga (Family empowerment post - which was shortened into Posdaya) was created as a forum for advocacy, communication, information, education to strengthen the coordination of activities of family functions. Regarding the main program is divided into four Posdaya essential that educational programs, health, economic, and environmental. Posdaya is formulated between and inter family, thus it will stresses in Posdaya personal basis, base groups, such as mosque-based Posdaya, Posdaya plant-based, or based Posdaya education, and more.

Posdaya advocates for the empowerment and active participation of all members in the family to strive for betterment. The Posdaya model combines and converges the MDGs, the eight functions of the families, and even the HDI into a single compact and streamlined concept for social development with the family as focus. Furthermore the Posdaya is a model for empowering all families, and nurtures harmony within the family and among families (Damandiri Foundation, 2010).

The number Posdaya in Indonesia at the moment is increasing. Since it was first established in the Village District Girimulya Cibungbulang, Bogor regency in 2007, it has now grown in number to 18,000 Posdaya in Indonesia (Damandiri Foundation, 2013). In order to oversee the process of growth, development and coaching Posdaya contained in the various regions, necessary to study the factors supporting and restraining the development of Posdaya. This study is needed to determine the factors supporting and restraining Posdaya for each field of activity, which in turn can be followed up with proper guidance and effective in every area of activity.

\section{Posdaya as Family Empowerment Program}

Muljono (2011) stated that Posdaya was created to respond the government's suggestion to build human resources through active participation in the family. The process of empowerment that prioritize of improving the family's ability to work hard eliminating ignorance, laziness and poverty in the broadest sense. The target 
activities are implementing joint effort so that every family has the ability to perform eight functions of families. For further development of Posdaya, Muljono (2010) stated that is need a reaffirmation of the goals of Posdaya, refresher of its committee members and cadres Posdaya, intensify the resocialization of Posdaya to all parties from the public, community leaders, village, district officials and local government and build productive business networks in an attempt community empowerment. In addition, there is need for the development and strengthening Posdaya activities on education, health, economy and environment. Posdaya as a participatory model of community development has proved to be successful performance as the program has produced positive changes in both physical and non physical of the society. These changes include the public opinion of the program and activities in education, health, economy and environmental development.

Empowerment evaluation is the use of evaluation concepts, techniques, and findings to foster improvement and self-determination. Empowerment evaluation has three steps: (1) establishing a mission, (2) take in stock, and (3) planning for the future. Empowerment evaluation helps to create a culture of learning and evaluation within an organization or community (Fetterman, 2002). Effective evaluation for human service programs is rapidly becoming more critical as a greater number of stakeholders demand documentation of a program's effectiveness. As a result, program evaluation needs to be relevant to a wide variety of constituents. Program evaluations must meet the needs of funding sources, policy makers, program staff, other critical audiences, and the program participants (Dunnagan, Duncan, \& Paul, 2000). The goal of the family empowerment program is to support the family in achieving their goals. This is accomplished through co-construction of a service plan that addresses the family's needs in an efficient and coherent manner-emphasizing family strengths and competencies and supporting family self-sufficiency (Cleek, Wofsy, Boyd-Franklin, Mundy, \& Howell, 2012).

Posdaya as a model of community empowerment in Indonesia has been implemented since 2006. This program has been established as part of community development program planned by Bogor Agricultural University for the empowerment of communities living around the campus. This present study was carried out to evaluate the implementation of Posdaya development at a village around the campus, Cikarawang village, particularly to evaluate the socialization of healthy environment campaign, economic development and extension for waste management. The site selection for the study was based on purposive consideration, as the Cikarawang village has never experienced to enjoy Posdaya Program. The result of the study showed that the community leaders and the cadres of Posdaya were aware about the existence of Posdaya as well as its functions and importance for the community empowerment. Based on the results of studies conducted by the community leaders and the cadres Posdaya can be seen that public knowledge about Posdaya relatively well and they have to understand what and how about Posdaya. But the general public has not been fully supportive because the concrete realization in the form of programs and impact developed by Posdaya not be realized in practice (Muljono, 2013c).

\section{Factors Affecting Performance of Posdaya}

The Management of Posdaya encountered both physical as well as non-physical constraints. Physical constraints which were related mainly to the limitations or lack of facilities and supporting facilities to run Posdaya activities. While non-physical constraints were related to improper understanding about Posdaya, the management capabilities of the board members are still weak, fed-up status of for the Posdaya board, the low quality of human resources, and the lack of the external support (Muljono, 2011). The Project potential generate economic benefits for the country by creating business opportunities and employment. The main economic driver of Posdaya is the potential to affect the livelihood strategies of small-scale enterprises and local entrepreneurs in the areas of: (1) natural capital (opportunities for gaining access to national government policies); (2) financial capital (communication with micro-credit and other lending organizations); (3) human capital (increased knowledge of new skills through distance learning and processes required for certification); (4) social capital (cultivation of contacts beyond the immediate community; and (5) physical capital. With improved rural connectivity, rural entrepreneurs will be able to upgrade their capital, which can be translated into better business opportunities (Muljono, 2010).

According to Muljono (2013a) based on the performance of a sample Posdaya studies generally have not reached the optimum score for each of the variable measured. Posdaya generally low performance on aspects of partnership, economic and environmental. While the secretariat, education and health aspects; the Posdaya performance is generally quite good. In another study, Muljono (2013b) stated that based on the results of studies conducted by the community leaders and the cadres Posdaya can be seen that public knowledge about Posdaya relatively well and they have to understand what and how about Posdaya. But the general public has not been fully supportive because the concrete realization in the form of programs and impact developed by Posdaya not realized in practice. Meanwhile, Man (1999) stated the results of his study demonstrated that the empowerment programme was effective for improving family participants' empowerment (total and individual) when facing 
challenges of brain injury. Both the total empowerment mean and the four individual empowerment means were found to have statistically significant improvement as a result of the empowerment programme.

A culturally sensitive empowerment model for Chinese communities may have to be gradual and harmonious and empower both the individual and his or her significant others (Yip, 2004). The research about an evaluation of a community intervention program directed towards assisting caregivers of mentally ill family members. The intervention program, implemented by the Edgewater/Uptown Community Mental Health Center, was based on a family empowerment model, such that the goal was to provide caregivers with the resources and skills necessary for effective and efficient caregiving for their mentally ill family member. The results indicate that the intervention had little effect. Only self-report measures of informal and formal social support were found to be significantly changed by the treatment program (Stock, 1990).

There are different relationships between types of participation and empowerment by gender. Gender did not have a significant main effect on empowerment, and its effects only became evident when it interacted with participation (Itzhaky \& York, 2000). By distinguishing between empowerment cognitions and empowerment acts, the effect of gender is tested on (a) the impact of empowerment and disempowerment acts on subordinates' empowerment cognitions, and (b) the direct impact of these acts on subsequent job satisfaction and performance. A total of 135 master of business administration students participated in a three-session simulation of the empowerment process. Findings indicate that although empowerment cognitions are affected by empowerment and disempowerment acts for both men and women, the impact of empowerment act on job satisfaction and performance varies by gender (Eylon \& Bamberger, 2000).

Based on quantitative face to face survey conducted on 500 residents in Lenggong Valley, the finding indicates that some of the local communities in Lenggong are already involved in entrepreneurship activities; however their business survivability should be a concern as they face limited financial sources and support. Furthermore, the majority of them are still involve in agricultural related activities making an indication that major effort is required to transform their life-style from agriculture to entrepreneurship. The finding provides a suggestion to the government on the needs to implement various entrepreneurship related programme in Lenggong Valley. Strategies to increase their involvement could be done through innovative programs, awareness, preparedness, and education on future entrepreneurs (Jaafar, Dahalan, \& Rosdi, 2014).

According to Zolfaghari, Sabran, \& Zolfaghari (2009) literacy plays an important role in Community Development (CD). Without literacy, people have difficulties improving their quality of life. Since the Islamic Revolution, the government of Iran has allocated great efforts and budgets on the literacy development to improve the quality of life. Following these efforts, the government has implemented various literacy programs. One of the major literacy programs that have been implemented for this purpose is the Community Learning Centers Program (CLCP). CLCP is the newest literacy program that has been implemented to develop literacy in order to improve the quality of life. CLCP has been emerged as a result of shortcomings of the previous literacy programs to solve the problem of illiteracy among people in the country. So far, the government of Iran has implemented 3517 CLCP into 3517 both rural and urban communities throughout the country.

Based on the research, it can be concluded that CLCP as educational tool has played very encouraging role in community literacy development in the community of Golshan in Iran. On the average, the level of literacy in the community has been promoted around $20 \%$ through CLCP during four years. On the overage, the annual growth level of literacy in this community is around 5\%. It can also be concluded that: what make the program famous is not merely because of the successful roles that the program have implemented, but what it makes more interesting is the fact that success of the program was depended more on the presence of effective activities and its relationship with other important factors such as local leaders, community participation, international organizations, good educators and government. All of the factors worked together to the success of CLCP. Each factor has its own advantages and strengths. Removing one factor will retard the process of achieving success. One factor is no more or less important than the others. All of literacy activities in CLCP at this community have been implemented effectively with cooperation of these factors. Otherwise, CLCP alone was not able to achieve this success (Zolfaghari, Sabran, \& Zolfaghari, 2009). After reviewing the analysis and the holistic view of the results, the following recommendations will be the best to promote the level of literacy among people at other participating communities in CLCP.

1. Organizing the strategic planning in CLCP

2. Attention to the needs of communities in writing the new literacy textbooks.

3. Capacity building of the CLCP personnel

4. Change of the communities-perception towards literacy 
5. Attention to the tongue language in literacy classes

6. Applying the new educational models in educating learners

7. Qualifying the literacy education and classes

8. Using new techniques such as media for learning.

Meanwhile, Ahmadian, Redzuan, Emby \& Samah (2010) stated that the current study presented the levels of community participation in community based program about breast cancer by women who have participated in mammography. Based on the findings of this study it can be concluded that, levels of women community participation are limited. But a community is empowered if its people are individually empowered. Thus, the persistence of benefits and activities within the enormous heterogeneity of communities would motivate participation at a higher level provided that they are individually empowered. Consequently, the sustainability of the health programs can be facilitated by community participation in programs to cooperate with health care professionals even though it is limited at low levels. On the other hand, policy makers should find the mechanisms to facilitate public participation in decision making, monitoring, evaluation and implementation. However, Iranian community participation in health programs is dominated by health care professionals.

In order to promote community participation in breast cancer prevention, factors that influence women participation in community-based program need to be understood to provide guiding framework for the planning, implementation and evaluation at higher levels of community participation in health. Furthermore, health care professionals must evolve a practical framework for the sustainability of health programs to help promote programs regarding breast cancer prevention. To date, a comprehensive evaluation of Iranian women community participation and breast cancer prevention has not been undertaken. Finding will be useful, for this at risk population (women) with emphasis on their role in their own health development and its sustainability (Ahmadian, Redzuan, Emby, \& Samah, 2010).

Research conducted in the city of Bekasi shows that the three exogenous latent variables, namely leadership, governance management, and governance ethic; able to improve the quality of well-being of poor families through the process of empowerment effectiveness. Empowerment process is implemented in the form of Posdaya (Suwito, 2014). Meanwhile Saleh, Rokhani \& Bahtiar (2014) stated that the development of social capital and entrepreneurial facing various problems of which the condition of human resources, planned programs, and mentoring. They suggest the presence of approaches and better communication to the stakeholders in the location of Posdaya. And then, research conducted by Sadono, Saharuddin \& Yusalina (2014) shows that mentoring has enough Posdaya able to improve the board's ability to manage and promote Posdaya. Analysis of customer satisfaction index (CSI) shows the pattern board Posdaya satisfied with the assistance that is done, while the member is quite satisfied.

\section{Methodology}

\subsection{Sampling}

Respondents in this study were the administrators and activists Posdaya located in Bogor City and Bogor District, West Java Province. Total Posdaya that has formed and established in Bogor were 68 units, and 50 units in Bogor District. From each Posdaya selected two administrators or activists Posdaya, so chosen as respondents 236 people. Other respondents i.e. 14 people are representatives of stakeholders who engaged in operational Posdaya activities in Bogor City and Bogor District consist of local government, lecturer and researcher from universities. The total of respondents are 250 people.

\subsection{Data Collection}

The data have been collected from the respondents using a questionnaire, then compiled for each field/aspect Posdaya activity based factors driving and restraining factors, specified weights, the score and the value of each item (statement) on the drivers and inhibitors for each field/aspect of the Posdaya. Data collection was conducted in August 2013by using force field analysis techniques. The procedure is carried out as follows:

\section{Step 1: Defining the Problem}

What is the nature of our current situation that is unacceptable and needs modification? It is useful to separate the specific problem from those things that Posdaya are working well.

\section{Step 2: Defining the Change Objective}

What is the desired situation that would be worth working toward? Be as specific as possible.

\section{Step 3: Identifying the Driving Forces}

What are the factors or pressures that support change in the desired direction of Posdaya? 
What are the relative strengths of these forces? What are the inter-relationships among the driving forces?

\section{Step 4: Identifying the Restraining Forces}

What are the factors or pressures that resist the proposed change and maintain the status quo at Posdaya? What are the inter-relationships among the restraining forces?

\section{Step 5: Developing the Comprehensive Change Strategy}

Although this is a relatively stable state, movement can be achieved altering the factors currently contributing to Posdaya equilibrium. Change can occur as a result of any combination of the following:

- strengthening any of the driving forces

- adding new driving forces (possibly by transforming a former restraining force)

- removing or reducing any of the restraining forces.

\subsection{Data Analysis Techniques}

Determination of the weights and scores for each item were analyzed descriptively, based on a compilation of opinions of all study respondents. The data analysis was done by using the Force Field Analysis (FFA). Force Field Analysis is a general tool for systematically analyzing the factors found in complex problems. It frames problems in terms of factors or pressures that support the status quo (restraining forces) and those pressures that support change in the desired direction (driving forces). A factor can be people, resources, attitudes, traditions, regulations, values, needs, desires, etc. which may affect the performance of Posdaya. As a tool for managing change, Force Field Analysis helps identify those factors that must be addressed and monitored if change is to be successful.

\section{Results}

The results of the force field analysis (FFA) conducted on four areas, namely the scope of activities Posdaya economics, education, health and the environment. Description of the results of the analysis of each field is as follows.

\subsection{Economic}

Table 1. Posdaya force field analysis results for economics

\begin{tabular}{|c|c|c|c|c|}
\hline A. & Driving & Weights & Scores & Grades \\
\hline 1. & Create positive economic change in society & 0,15 & 3,37 & 0,49 \\
\hline 2. & Rising prices & 0,07 & 2,47 & 0,18 \\
\hline 3. & The availability of sufficient labor & 0,02 & 3,10 & 0,06 \\
\hline 4. & Regular social gathering & 0,16 & 3,16 & 0,52 \\
\hline 5. & Partnering with large companies & 0,05 & 3,26 & 0,18 \\
\hline 6. & Business activities based on local resources & 0,18 & 3,29 & 0,60 \\
\hline 7. & Economic empowerment of local government policy & 0,13 & 3,32 & 0,42 \\
\hline 8. & Small micro enterprises development program & 0,09 & 3,32 & 0,30 \\
\hline 9. & Financial institutions that pro-poor & 0,04 & 3,36 & 0,12 \\
\hline \multirow[t]{2}{*}{10.} & Government's poverty alleviation program & 0,11 & 3,37 & 0,37 \\
\hline & & 1,00 & & 3,23 \\
\hline B. & Restraining & Weights & Scores & Grades \\
\hline 1. & His efforts have not been known to the market & 0,18 & 3,12 & 0,57 \\
\hline 2. & The entry of imported products at low prices & 0,09 & 3,10 & 0,28 \\
\hline 3. & Cheap agricultural product prices & 0,05 & 2,98 & 0,16 \\
\hline 4. & Decreased purchasing power & 0,07 & 3,09 & 0,22 \\
\hline 5. & Disparity / economic disparities between regions & 0,04 & 2,98 & 0,11 \\
\hline 6. & Limited involvement of donors or investors & 0,11 & 3,17 & 0,35 \\
\hline 7. & Delays the development of small businesses & 0,15 & 3,19 & 0,46 \\
\hline 8. & The amount of family & 0,16 & 3,17 & 0,52 \\
\hline 9. & High interest rates & 0,02 & 3,32 & 0,06 \\
\hline \multirow[t]{2}{*}{10.} & Do not have savings and assets & 0,13 & 3,23 & 0,41 \\
\hline & & 1,00 & & 3,14 \\
\hline
\end{tabular}


Posdaya force field analysis results in economics show that the thrust of (3.23) is stronger than the inhibitory power (3.14), as listed in Table 1 means that economic development in the overall Posdaya are moving in a positive direction. In other words, the economy is growing Posdaya driven by locally-based businesses and activities of group gathering.

Table 1 describes another driving factor in economic development, the government policy in the fields of economy, both local and central government. The thrust of economic development Posdaya derived from internal factors (Strength), which is locally based business activities and gathering activities, while external factors (Opportunity) is the change in economic conditions in the community and economic empowerment policies. However, the inhibition of the economic development Posdaya also come from internal factors (Weakness), the effort is not yet known and the market size of family dependents. Inhibition of external factors (Threats) is the entry of imported products and the declining purchasing power.

Thus Posdaya economic development will continue to grow and develop and it is possible with the power that is able to cover its weaknesses. In these conditions the alternative strategies that could be developed is in the form of an intensive strategy of product development and market penetration strategy or strategies or forward WO (Weakness-Opportunity) for example, developing market linkages and promotion program of local government.

\subsection{Education}

Posdaya force field analysis results indicate that the educational thrust (3.33) is stronger than the inhibitory power (3.14). This means that the development of education in the overall Posdaya are moving in a positive direction. Nevertheless, Posdaya still need funding educational scholarships and community support (Table 2).

Table 2. Posdaya Force Field Analysis Results for Education

\begin{tabular}{|c|c|c|c|c|}
\hline A. & Driving & Weights & Scores & Grades \\
\hline 1. & Capacity building society & 0,15 & 3,43 & 0,50 \\
\hline 2. & Free three blind (illiterate, blind numbers, blind language) & 0,09 & 3,33 & 0,30 \\
\hline 3. & There is always a tough and skilled cadre & 0,18 & 3,41 & 0,62 \\
\hline 4. & Training and human resource development & 0,16 & 3,31 & 0,54 \\
\hline 5. & A catch-up program package (equivalent elementary school)) & 0,07 & 3,22 & 0,23 \\
\hline 6. & Availability of teacher & 0,13 & 3,27 & 0,42 \\
\hline 7. & Facilities of libraries & 0,04 & 3,27 & 0,12 \\
\hline 8. & Teaching and learning facilities & 0,11 & 3,29 & 0,36 \\
\hline 9. & Availability of curriculum & 0,05 & 3,24 & 0,18 \\
\hline \multirow[t]{2}{*}{10.} & Source of fund scholarships & 0,02 & 3,36 & 0,06 \\
\hline & & 1,00 & & 3,33 \\
\hline B. & Restraining & Weights & Scores & Grades \\
\hline 1. & Soft skills of Posdaya cadres are still low & 0,18 & 3,20 & 0,58 \\
\hline 2. & Dependence on instructor & 0,09 & 3,08 & 0,28 \\
\hline 3. & The spirit sailed unstable & 0,13 & 3,14 & 0,40 \\
\hline 4. & Regeneration board does not run & 0,11 & 3,14 & 0,34 \\
\hline 5. & Instant culture character & 0,16 & 3,12 & 0,51 \\
\hline 6. & Low educational level & 0,05 & 3,07 & 0,17 \\
\hline 7. & Not all citizens know and understand Posdaya & 0,02 & 3,14 & 0,06 \\
\hline 8. & Lack of co-ordination meeting schedule & 0,15 & 3,12 & 0,45 \\
\hline 9. & Educational facilities minimalist & 0,04 & 3,14 & 0,11 \\
\hline \multirow[t]{2}{*}{10.} & The lack of initiative to do consulting & 0,07 & 3,14 & 0,23 \\
\hline & & 1,00 & & 3,14 \\
\hline
\end{tabular}

Table 2 shows that in Posdaya always a cadre of tough and skilled in developing education (0.62). Cadre is what moves Posdaya educational activities, because in addition to training and human resource development programs by the government as well as capacity building is a focal point of Posdaya companion. In addition, the availability of teachers and learning facilities is a driving factor being the power of Posdaya.

Nevertheless, overall, the soft skills of Posdaya human resource still needs to be improved, as it becomes a major weakness of Posdaya factor (0.58). This happens because in the instant culture growing community, where education process that usually takes time to be biased, because people want immediate results can be seen. This instant culture become a serious threat to the development of Posdaya. 
Overall external factors dominate the direction of educational Posdaya development. This means that Posdaya in developing educational activities need the support of other parties, in this case the government and the public. Therefore, alternative strategies that could be implemented are the integration strategy in collaboration with other institutions or strategy ST (Strength-Threats) establish partnerships with institutions such as the source of funds.

\subsection{Health}

Results Posdaya force field analysis in the field of health show that thrust (3.35) is stronger than the inhibitory power (3.10). This means that development in Posdaya overall health is moving in a positive direction. Nevertheless, there are still more Posdaya believe in mystical things that need at the support of other parties in providing an understanding of a more rational health (Table 3 ).

Table 3. Posdaya Force Field Analysis Results for Health

\begin{tabular}{|c|c|c|c|c|}
\hline A. & Driving & Weights & Scores & Grades \\
\hline 1. & Controlling the health of every month, sick or not sick & 0,13 & 3,39 & 0,43 \\
\hline 2. & Regular program service center & 0,18 & 3,38 & 0,62 \\
\hline 3. & Health services in place & 0,11 & 3,26 & 0,36 \\
\hline 4. & Health screening at no cost & 0,07 & 3,36 & 0,24 \\
\hline 5. & Cheap drugs & 0,05 & 3,44 & 0,19 \\
\hline 6. & Regular blood pressure checks & 0,04 & 3,33 & 0,12 \\
\hline 7. & The presence of a midwife / doctor regularly & 0,09 & 3,39 & 0,31 \\
\hline 8. & The existence of the learning process, such as nutrition classes & 0,15 & 3,25 & 0,47 \\
\hline 9. & Health care 24 hours & 0,16 & 3,40 & 0,56 \\
\hline \multirow[t]{2}{*}{10.} & Provide input / feedback in terms of health & 0,02 & 3,26 & 0,06 \\
\hline & & 1,00 & & 3,35 \\
\hline B. & Restraining & Weights & Scores & Grades \\
\hline 1. & Low government subsidies & 0,09 & 3,23 & 0,29 \\
\hline 2. & Accessibility of service is low & 0,16 & 3,16 & 0,52 \\
\hline 3. & There is no health insurance & 0,04 & 3,10 & 0,11 \\
\hline 4. & Cannot access health information programs & 0,13 & 3,07 & 0,39 \\
\hline 5. & More faith in mystical & 0,02 & 2,87 & 0,05 \\
\hline 6. & Healthy culture that is low & 0,18 & 3,05 & 0,55 \\
\hline 7. & Food consumption patterns of uneven & 0,11 & 3,06 & 0,33 \\
\hline 8. & No sports facilities & 0,07 & 3,12 & 0,23 \\
\hline 9. & Medicine is expensive & 0,05 & 3,17 & 0,17 \\
\hline \multirow[t]{2}{*}{10.} & Unskilled cultivate medicinal plants & 0,15 & 3,08 & 0,45 \\
\hline & & 1,00 & & 3,10 \\
\hline
\end{tabular}

Table 3 explains that the routine activities in integrated services are the driving factor that is very strong with a great opportunity to follow the process of learning about the nutritional and healthy food. More personalized service and can be obtained at any time ( 24 hours) encourage Posdaya to develop activities in the field of health. Nevertheless, Posdaya still requires a means of funding a more adequate health infrastructure and knowledge of integrated environmental health.

In addition, the inhibition of which are derived from external factors that healthy cultural community is very low. This is a result of not skilled Posdaya develop medicinal plants and unbalanced consumption patterns. Therefore, accessibility to health Posdaya cheap and quality still needs to be improved, either through their own efforts and the help of other parties, for example by organizing sports facilities and other health facilities.

Furthermore, more motivating factor derived from internal factors (Strengths) Posdaya, whereas inhibitors and factor derived from external factor (Threat). This means that the issue of health is largely determined by the role of other parties, such as local government or escort agencies of Posdaya. This indicates that Posdaya role in developing health activities require thorough and consistent support from the government and other stakeholders Posdaya.

Thus, alternative strategies that could be developed are the integration strategy by working with health institutions, both public and private, on a regular basis. Comprehensive environmental health program becomes 
the main focus Posdaya forward. Therefore the strategy of WO (Weakness-Opportunity) can be run, for example by developing medicinal plants and conduct periodic monitoring of environmental health.

\subsection{Environment}

Posdaya force field analysis results indicate that the environmental field thrust (3.27) is stronger than the inhibitory power (3.13). This means that the development of the overall environment in Posdaya is moving in a positive direction. Spirit of mutual help Posdaya still very strong, but the culture gathering has begun to diminish Therefore, the spirit of mutual cooperation should be maintained by providing awareness of the importance of environmental management for future next generation.

Table 4. Posdaya force field analysis results for environment

\begin{tabular}{|c|c|c|c|c|}
\hline A. & Driving & Weights & Scores & Grades \\
\hline 1. & The spirit of mutual cooperation and self-reliance & 0,18 & 3,42 & 0,62 \\
\hline 2. & Network partnership of Posdaya & 0,04 & 3,32 & 0,12 \\
\hline 3. & Lifestyle back to nature & 0,16 & 3,21 & 0,53 \\
\hline 4. & The number of institutions pro greening & 0,13 & 3,17 & 0,40 \\
\hline 5. & Government programs to avoid natural disasters & 0,07 & 3,30 & 0,24 \\
\hline 6. & Composting program and biophore & 0,05 & 3,22 & 0,18 \\
\hline 7. & Agritourism development and ecotourism & 0,11 & 3,16 & 0,34 \\
\hline 8. & Competition environmental hygiene & 0,09 & 3,32 & 0,30 \\
\hline 9. & Household waste management program & 0,15 & 3,33 & 0,48 \\
\hline \multirow[t]{2}{*}{10.} & Global warming issues & 0,02 & 3,07 & 0,06 \\
\hline & & 1,00 & & 3,27 \\
\hline B. & Restraining & Weights & Scores & Grades \\
\hline 1. & Facilities and infrastructure empowerment potluck & 0,11 & 3,13 & 0,34 \\
\hline 2. & Low accessibility information & 0,13 & 3,14 & 0,40 \\
\hline 3. & Weak initiative and culture come together & 0,16 & 3,15 & 0,52 \\
\hline 4. & Political instability at centers or regional & 0,04 & 3,16 & 0,12 \\
\hline 5. & A builder and narcissistic society that has existed & 0,05 & 2,98 & 0,16 \\
\hline 6. & Low support in the area of environmental forces Posdaya & 0,09 & 3,16 & 0,29 \\
\hline 7. & Do not have a multi-purpose building as a center of activity & 0,02 & 3,18 & 0,06 \\
\hline 8. & The absence of a productive business activities & 0,07 & 3,18 & 0,23 \\
\hline 9. & The presumption Posdaya as project & 0,18 & 3,08 & 0,56 \\
\hline \multirow[t]{2}{*}{10.} & Low environmental care group & 0,15 & 3,16 & 0,46 \\
\hline & & 1,00 & & 3,13 \\
\hline
\end{tabular}

Table 4 shows that the lifestyle of the people back to nature is external factors (opportunities) that are able to make Posdaya developing environment. Household waste management programs and the development of agro-tourism or ecotourism is an alternative that can be developed by Posdaya in managing the environment. However, even if it is not too large driving force, global warming issues also play a role in Posdaya awareness of the importance of environmental regulation.

Inhibition in environmental regulation is the public perception is that Posdaya project. This makes the public apathy towards Posdaya, because the project is considered the interests of the government and the public do not get the benefits. This assumption also indicates that Posdaya project will not last long, so it does not require the intervention of society in environmental regulation. Therefore, the need of regeneration groups that can make environmentally conscious society proactively contribute to environmental regulation.

Thus, an alternative strategy that can be executed is a form of aggressive strategy formation or group of environmentally conscious strategies SO (Strength-Opportunity) as restore back the culture of mutual aid and life back to nature. The arrangement does not directly benefit the Posdaya, because there is a lag time, but it would be beneficial for the next generation in developing Posdaya other activities, whether economic, educational, and health. Based on the analysis of the force field that has been done, then the next can be formulated goals, objectives, strategies, policies, programs and activities of Posdaya to the economic, educational, health, and environment (Table 5). 


\section{Discussion}

Based on the analysis of the force field Posdaya four areas of development activity, in general the value of the driving factors is higher than the value of limiting factors. This indicates that Posdaya be in a position to grow and develop, therefore a driving force more powerful than the inhibitory power. Participants Focus Group Discussion of group decision makers, universities and local government suggests the existence of several barriers to the development of Posdaya, among which is the condition of human resources, assistance, coordination and communication in the field, as well as the type of program.

In terms of human resources, lack of motivation in the development of society and the difficulty invites cooperation between people in community empowerment of citizens to be the cause of stagnant Posdaya activity. Some of them stopped altogether in developing Posdaya activities. Lack of expertise and knowledge in the organization is also one of the causes of underdevelopment in Posdaya. Posdaya require assistants as partners in moving society, excavation of ideas, and as a friend to discuss and exchange opinions as well as a source of information and innovation Posdaya development. However, due to limited financial resources available to facilitate the Posdaya assistants tend to slow movement.

Relevant Department has a program to empower the community, the service also has a field officer on duty to empower the community in accordance with the official program. However inter institutions, leadership, and the field officers have not entwined coordinate program implementation although their program objectives are the same community. Even impressed between agencies can not be bothered by programs of other agencies. In addition, the program has not established synergism between PKK (Program Kesejahteraan Keluarga or Family Welfare Program) with relevant agencies and universities in developing Posdaya. Musrenbang (deliberation development plan) at the local level so far not offend Posdaya target when it is very comprehensive.

Table 5. Preparation of Posdaya Action Plan

\begin{tabular}{|c|c|c|c|c|c|c|}
\hline Nu. & Objective & Target & Strategy & Policy & Program & Activity \\
\hline 1. & $\begin{array}{l}\text { Improving the } \\
\text { performance of } \\
\text { the economic } \\
\text { aspects of } \\
\text { Posdaya }\end{array}$ & $\begin{array}{l}\text { Improving the } \\
\text { performance of the } \\
\text { economic aspect to } \\
\text { be productive and } \\
\text { creative Posdaya }\end{array}$ & $\begin{array}{l}\text { To improve the } \\
\text { performance of } \\
\text { the economic } \\
\text { aspects of } \\
\text { Posdaya }\end{array}$ & $\begin{array}{l}\text { Recommends that } \\
\text { Posdaya } \\
\text { complements } \\
\text { economic elements } \\
\text { that have not been } \\
\text { developed }\end{array}$ & $\begin{array}{l}\text { Improved } \\
\text { economic } \\
\text { performance } \\
\text { of Posdaya }\end{array}$ & $\begin{array}{l}\text { Posdaya economic } \\
\text { arrangement according to } \\
\text { the potential and capacity of } \\
\text { the community, as well as } \\
\text { business opportunities } \\
\text { based on local resources }\end{array}$ \\
\hline 2. & $\begin{array}{l}\text { Improving the } \\
\text { performance of } \\
\text { education } \\
\text { aspects of } \\
\text { Posdaya }\end{array}$ & $\begin{array}{l}\text { Improving the } \\
\text { performance of } \\
\text { education aspect of } \\
\text { Posdaya orderly, to } \\
\text { be effective and } \\
\text { efficient }\end{array}$ & $\begin{array}{l}\text { To improve the } \\
\text { performance of } \\
\text { education } \\
\text { aspect of } \\
\text { Posdaya }\end{array}$ & $\begin{array}{l}\text { Recommends that } \\
\text { Posdaya } \\
\text { complementary for } \\
\text { incomplete elements } \\
\text { of education }\end{array}$ & $\begin{array}{l}\text { Improved } \\
\text { educational } \\
\text { performance } \\
\text { of Posdaya }\end{array}$ & $\begin{array}{l}\text { Structuring Posdaya } \\
\text { appropriate education } \\
\text { potentials and capabilities } \\
\text { of the community by } \\
\text { utilizing a cadre of tough } \\
\text { and skilled }\end{array}$ \\
\hline 3. & $\begin{array}{l}\text { Improving the } \\
\text { performance of } \\
\text { health aspects } \\
\text { of Posdaya }\end{array}$ & $\begin{array}{l}\text { Improving the } \\
\text { performance of } \\
\text { health aspects } \\
\text { Posdaya orderly, to } \\
\text { be effective and } \\
\text { efficient }\end{array}$ & $\begin{array}{l}\text { To improve the } \\
\text { performance of } \\
\text { the health } \\
\text { aspects of } \\
\text { Posdaya }\end{array}$ & $\begin{array}{l}\text { Recommends that } \\
\text { Posdaya supplement } \\
\text { any incomplete } \\
\text { health elements }\end{array}$ & $\begin{array}{l}\text { Improved } \\
\text { health } \\
\text { performance } \\
\text { of Posdaya }\end{array}$ & $\begin{array}{l}\text { Posdaya appropriate } \\
\text { structuring potential health } \\
\text { and community capabilities, } \\
\text { as well as routine health } \\
\text { care program }\end{array}$ \\
\hline 4. & $\begin{array}{l}\text { Improving the } \\
\text { performance of } \\
\text { environmental } \\
\text { aspects of } \\
\text { Posdaya }\end{array}$ & $\begin{array}{l}\text { Improving the } \\
\text { performance of } \\
\text { environmental } \\
\text { aspects of Posdaya } \\
\text { orderly, to be } \\
\text { effective } \\
\text { efficient }\end{array}$ & $\begin{array}{l}\text { To improve the } \\
\text { environmental } \\
\text { performance } \\
\text { aspects of } \\
\text { Posdaya }\end{array}$ & $\begin{array}{l}\text { Suggested that } \\
\text { Posdaya } \\
\text { complement any } \\
\text { incomplete } \\
\text { environmental } \\
\text { elements }\end{array}$ & $\begin{array}{l}\text { Improved } \\
\text { environmental } \\
\text { performance } \\
\text { of Posdaya }\end{array}$ & $\begin{array}{l}\text { The arrangement according } \\
\text { to the potential and ability } \\
\text { Posdaya community, as } \\
\text { well as the spirit of mutual } \\
\text { cooperation and } \\
\text { self-reliance. }\end{array}$ \\
\hline
\end{tabular}

Community empowerment is no longer in accordance with the wear pattern of the project. The activities carried out in a particular fiscal year. But it does not continue in the program next year. Posdaya includes 8 families, but the tendency of local government functions only support the economic sector. In general the attention and 
support of the local government to Posdaya still small. In addition, existing government programs tend to be largely patterned to give, not empowering, so that people are encouraged to behave in a request and wait, do not take the initiative.

On the other hand, quite a lot of potential for development Posdaya spread in the community. Self-help groups is the potential that generally has a lot of growing as farmers' groups, gathering groups, women farmer groups, study groups, Early Childhood Education (ECD), and others. Communities in the region Posdaya also showed positive support in the effort to empower the community together Posdaya. Physical support, among others, demonstrated by their willingness to use private property for the purposes of the empowerment process for instance used for early childhood area, private land for garden plots nutritious, home residence as Posdaya secretariat and also as a place of health care, and also contributed funding to support a variety of Posdaya activities.

Sacrifices in terms of human resources are also shown by the people who are willing to take charge and cadres Posdaya. They are actively engaged in four fields of activity along Posdaya empowerment without material reward. Even as a well-established among administrators willing to help fund requirements for other cadres to move Posdaya program.

In terms of potential local government development programs that exist in local government it is possible to build programs Posdaya as an example is the support of economic development by the Bogor Regency, and support training programs by the Bogor municipal government. In addition, the regional head and she actually really respect regent with Posdaya. Nuance to make Posdaya as common property, including property of each Department is also quite possible, so Posdaya can simultaneously act as a mediator decay sectoral ego.

Universities are expected to be able to access / assist Posdaya overall in the district and in the city so that its development is more evenly distributed. Universities are also expected to combine various empowerment programs regardless of the source program alone. Because the pattern of funding from the government was constrained by time while the empowerment process is supposed to take place continuously.

\section{Conclusion}

Based on the analysis of the force field Posdaya four areas of development activity, in general the value of the driving factors is higher than the value of limiting factors. This indicates that Posdaya be in a position to grow and develop, therefore a driving force more powerful than the inhibitory power. Stakeholders of Posdaya suggest the existence of several barriers to the development of Posdaya, among which is the condition of human resources, assistance, coordination and communication in the field, as well as the type of program.

The analysis showed that the most prominent driving factor for the economic, education, health and the environment is business activities based on local resources; there is always a tough and skilled cadre; regular program service centre, Posbindu, Posyandu; and the spirit of mutual cooperation and self reliance. Meanwhile, the most prominent obstacle to the economic, education, health and the environment is not been known to the market, soft skills of Posdaya cadre are still low, healthy culture is low, and the presumption Posdaya as project. Based on the results of the analysis can be developed appropriate programs and activities to improve performance and overcome the weaknesses of Posdaya.

\section{Acknowledgements}

Gratitude to the Ministry of Education and Culture of the Republic of Indonesia, which has funded this research. The Board of Posdaya around the region of Bogor City, Bogor District, and stakeholders of Posdaya that has pleased the respondents in this study. Thanks to Mr. Burhanuddin and Mrs. Ratri Viriantina who have helped in the process of this research.

\section{References}

Ahmadian, M., Redzuan, M., Emby, Z., \& Samah, A. A. (2010). Women's community partici-pation levels in community-based health programs regarding breast cancer prevention in metropolitan Tehran, Iran. Asian Social Science, 6(9), 12-21. http://dx.doi.org/10.5539/ass.v6n9p12

Cleek, E. N., Wofsy, M., Boyd-Franklin, N., Mundy, B., \& Howell, T. J. (2012). The family empowerment program: an interdisciplinary approach to working with multi-stressed urban families. Family Process, 51(2), 207-217. http://dx.doi.org/10.1111/j.1545-5300.2012.01392.x

Damandiri Foundation. (2010). MDGs and the Eight Functions of Indonesian Families: Refreshing the paradigm for family development. Jakarta: Damandiri Foundation.

Damandiri Foundation. (2013). Final Report of Community Empowerment Program in Indonesia. Jakarta: 
Damandiri Foundation.

Dunnagan, T., Duncan, S. F., \& Paul, L. (2000). Doing efective evaluations: a case study of family empowerment due to welfare reform. Evaluation and Program Planning, 23, 125-136. http://dx.doi.org/10.1016/S0149 $-7189(99) 00048-8$

Eylon, D., \& Bamberger, P. (2000). Empowerment cognitions and empowerment acts: Recogni-zing the importance of gender. Group \& Organization Management, 25(4), 354-372. http://dx.doi.org/10.1177/ 1059601100254003

Fetterman, D. M. (2002). Empowerment evaluation: building communities of practice and a culture of learning. American Journal of Community Psychology, 30(1), 89-102. http://dx.doi.org/10.1023/A:1014324218388

Itzhaky, H., \& York, A. S. (2000). Empowerment and community participation: Does gender make a difference? Social Work Research, 24(4), 225-234. http://dx.doi.org/10.1093/swr/24.4.225

Jaafar, M., Dahalan, N., \& Rosdi, S. A. M. (2014). Local community entrepreneurship: a case study of the Lenggong Valley. Asian Social Science, 10(10), 226-235. http: //dx.doi.org/10.5539/ass.v10n10p226

Man, D. (1999). Community-based empowerment programme for families with a brain injured survivor: an outcome study. Brain Injury, 13(6), 433-445. http://dx.doi.org/10.1080/026990599121485

Muljono, P. (2010). The Posdaya model for community empowerment. Journal of Community, Culture and Politics, 23(1), 9-16.

Muljono, P. (2011). The model of family empowerment program for community development in West Java, Indonesia. Journal of Agricultural Extension and Rural Development, 3(11), 193-201.

Muljono, P. (2013a). Performance evaluation of Posdaya as family empowerment model in Indonesia. Asian Journal of Humanities and Social Studies, 1(4), 173-178.

Muljono, P. (2013b). Replication of Posdaya for community empowerment programe: case study at Situgede Village, Bogor, Indonesia. Asian Journal of Humanities and Social Sciences, 1(3), 1-8.

Muljono, P. (2013c). The Role of Posdaya in Shaping Community Empowerment: Case study at Cikarawang Village, Bogor, Indonesia. Asian Journal of Humanities and Social Studies, 1(5), 225-232.

Sadono, D., Saharuddin, \& Yusalina. (2014). Customer satisfaction index for family empowerment program. Journal of Social Welfare, 1(1), 1-12. Retrieved from http://www.universitas-trilogi.ac.id/journal/ ks.

Saleh, A., Rokhani, \& Bahtiar, R. (2014). Support external relations and entrepreneurship through social capital model againt Posdaya in Bogor and Cianjur district. Journal of Social Welfare, 1(1), 25-38. Retrieved from http://www.universitas-trilogi.ac.id/journal/ks.

Stock, J. G. (1990). An evaluation of family empowerment treatment program. Chicago: University of Illinois.

Suwito, S. (2014). The effectiveness of empowerment program. Journal of Social Welfare, 1(1), 13-24. Retrieved from http://www.universitas-trilogi.ac.id/journal/ks.

Suyono, H., \& Haryanto R. (2009). Handbook of Posdaya Development. Jakarta: Balai Pustaka.

Yip, K. S. (2004). The empowerment model: a critical reflection of empowerment in Chinese culture. Social Work, 49(3), 479-487. http://dx.doi.org/10.1093/sw/49.3.479

Zolfaghari, Ak., Sabran, S. M., \& Zolfaghari, Az. (2009). Community learning centers program as an educational tool for community literacy development in the Islamic Republic of Iran: community of Golshan as a case study. Asian Social Science, 5(8), 60-66. http://dx.doi.org/10.5539/ass.v5n8p60

\section{Copyrights}

Copyright for this article is retained by the author(s), with first publication rights granted to the journal.

This is an open-access article distributed under the terms and conditions of the Creative Commons Attribution license (http://creativecommons.org/licenses/by/3.0/). 